\title{
Is there evidence for neuropsychological and neurobehavioral phenotypes among adults without FXTAS who carry the FMR 1 premutation? A review of current literature
}

\author{
Jessica Ezzell Hunter, $M S^{l}$, Ann Abramowitz, PhD ${ }^{2}$, Michele Rusin, PhD', \\ and Stephanie L. Sherman, $P h D^{1}$
}

\begin{abstract}
Carriers of expanded, but unmethylated, premutation alleles of the fragile X mental retardation gene are at risk for a late-onset tremor/ ataxia syndrome, mostly affecting men over age 50 . However, the general neuropsychological and neurobehavioral impact of carrying a premutation allele in younger adults not affected by the tremor/ataxia syndrome remains unclear. Past studies have utilized varying study designs resulting in inconsistent conclusions. To better understand the current evidence of the influence of the premutation on such traits in adult carriers, we reviewed the literature and identified 16 studies that met conservative inclusion criteria, including molecular measures of the fragile $\mathrm{X}$ mental retardation gene CGG triplet repeat length and standard measures of neurobehavioral and neurocognitive phenotypes. A review of these studies is presented to assess the evidence for possible premutation-associated neuropsychological deficits among adult men and women who do not meet diagnostic criteria of the tremor/ataxia syndrome. Results of these studies, and possible reasons for inconsistent conclusions, are discussed. The primary conclusion from this review is the need for further research using a standard protocol in a large multisite project to ensure the necessary sample size. Genet Med 2009:11(2):79-89.
\end{abstract}

Key Words: FMR1, CGG repeat, premutation, fragile $X$ syndrome, FXTAS, neuropsychology, cognition, anxiety, depression

$\mathrm{T}$ he $\mathrm{X}$-linked fragile $\mathrm{X}$ mental retardation gene (FMR1) contains a triplet CGG repeat in the $5^{\prime}$ untranslated region that is associated with the mental retardation syndrome, fragile $\mathrm{X}$ (FXS). ${ }^{1-3}$ The most common alleles of FMRI contain $<40$ repeats and are stable when transmitted from generation to generation., ${ }^{4,5}$ Because of mechanisms that are presently unclear, the triplet repeat can become unstable and expand from one generation to the next. Expansion to $>200$ repeats results in hypermethylation of the FMR1 gene and subsequent loss of gene expression. ${ }^{6-9}$ The loss of the protein product, fragile $\mathrm{X}$ mental retardation protein (FMRP), is responsible for FXS. ${ }^{8}, 10$ Males with FXS typically have mild to severe mental retardation, developmental delay, hyperactivity, social anxiety and other anxiety disorders, and autistic-like features. In addition, males with FXS display a pattern of memory

From the ${ }^{1}$ Department of Human Genetics, Emory University School of Medicine; ${ }^{2}$ Department of Psychology, Emory University; and ${ }^{3}$ Independent Practice, Atlanta, Georgia

Stephanie Sherman, PhD, Department of Human Genetics, Emory University, 615 Michael Street, Whitehead Biomedical Research Building, Suite 301, Atlanta, Georgia 30322. E-mail: ssherma@emory.edu

Disclosure: The authors declare no conflict of interest.

Submitted for publication June 20, 2008

Accepted for publication September 15, 2008

DOI: $10.1097 /$ GIM.0b013e31818de6ee deficits, particularly for short-term, or working memory, and visual memory. ${ }^{11-14}$

Expanded, but unmethylated, repeats in the range of about 55-200 are unstable across generations ${ }^{5}$ and are associated with increasing levels of transcript and decreasing levels of FMRP. ${ }^{15-18}$ These FMRI alleles, termed premutation alleles, have recently been found to be associated with a late-onset fragile X-associated tremor ataxia syndrome (FXTAS), mostly affecting men after the age of 50.19,20 Men with FXTAS typically develop a progressive tremor and/or ataxia and experience cognitive decline, loss of executive function and short-term memory, as well as irritability and anxiety. ${ }^{19,20}$

Thus cognitive, memory, and executive function impairments as well as neurobehavioral issues are shared phenotypes of FXS and FXTAS for males and to a lesser degree for females because of the X-linked nature of FMR1. Further, FXS is the result of a lack of FMRP expression, ${ }^{8}$ whereas symptoms of FXTAS are caused by a toxic gain of function of the expanded FMR1 transcript present in premutation allele carriers. ${ }^{21}$ Given these phenotypes associated with FMRI and the molecular phenotypes associated with premutation alleles, specifically increased transcript levels and reduced FMRP, ${ }^{15-18}$ global impairment in neuropsychological functioning associated with premutation alleles may be expected among adult carriers of the premutation. In addition, brain anomalies have been reported among carriers of premutation alleles that do not meet diagnostic criteria of FXTAS. ${ }^{22-24}$ Aside from potential biological causes of neuropsychological and neurobehavioral phenotypes, the potential impact of environmental factors, including the stress of raising a child with FXS and the stigma of carrying a genetic mutation, should be considered as well.

Many studies have been conducted to characterize potential cognitive or behavioral deficits among premutation carriers. However, many were done before the characterization of FXTAS. For those whose study populations included premutation carriers over the age of 50, any reported deficits are difficult to interpret as general impairments among premutation carriers or as impairments resulting from inclusion of carriers affected by FXTAS. Among all studies, results tend to be contradictory and many are compromised by poor study design. Also, most studies have utilized female study populations when males would be more informative because of the X-linked nature of FMR1.

Thus, the strength of evidence in support of a phenotype among premutation adults is unclear. Despite the conflicting results from the published studies, anecdotal information suggesting significant deficits has become relevant in the clinical setting and in the fragile X community. This information is perpetuated in families and can result in potentially needless stress and anxiety. The purpose of this review is to critically 
evaluate the current literature for evidence of neuropsychological phenotypes among adults who carry the premutation in the absence of FXTAS. Using strict inclusion criteria outlined in Methods section we identified 16 studies that examine these phenotypes associated with premutation alleles in adult carriers.

\section{METHODS}

Articles for this review were identified by performing literature searches in PubMed and MEDLINE. The key words used in database searches in varying combinations were $F M R 1$, premutation, fragile X, neuropsychology, and phenotype. Articles published before November 2006 were included in the search and were limited to those published in English. To select the articles to be included in the review, the abstracts were reviewed, and the full text was retrieved for those that were relevant. Additional articles were identified through reviewing bibliographies of retrieved articles. Initial inclusion criteria for articles in this review were (1) standard molecular measures of repeat length were used, including polymerase chain reaction and/or Southern blotting of the CGG repeat region of FMR1, (2) subjects were directly assessed using standardized, valid, and reliable measures of neuropsychological and neurobehavioral phenotypes (i.e., any analysis that used family report methods or unstructured self-report methods were not included), (3) subjects were limited to those who were 18 years of age or older, (4) a noncarrier comparison group was referenced in the study, which could include family controls, general population controls, and/or a normative sample, (5) statistical methods with reported $P$ values were used, and (6) the article was published in a peer-reviewed journal. Nineteen published studies met the inclusion criteria outlined earlier. However, several issues remained to be addressed.

First, a proportion of the 19 articles that met the criteria earlier included study participants over the age of 50 who carried the premutation. Unless subjects were assessed for the presence or absence of FXTAS symptoms, the inclusion of these older subjects, particularly men, with the premutation could compromise the study results. This is due to the fact that older carriers of the premutation may have cognitive deficits and behavioral changes associated with FXTAS. ${ }^{20,25}$ Thus, it would be difficult to conclude whether any deficits detected among carriers were due to the late-onset neurodegeneration associated with FXTAS or because of a global impairment of carrying a premutation allele. To minimize this potential complication, all studies that included premutation men over the age of 50 were excluded. This reduced the number of studies in the review from 19 to 16 . Although women with a premutation are also at risk of developing FXTAS, studies that met all other inclusion criteria outlined earlier, but included women over the age of 50, were nonetheless included in this review. We made this exception as FXTAS seems to act as an X-linked recessive disorder; it is significantly less common among women compared with men who carry the premutation, and symptoms of FXTAS for women are much milder than those among men. ${ }^{26}$

Second, the focus of some articles retrieved was to characterize phenotypes of full mutation carriers, whereas a premutation carrier group was included in the study for comparison purposes. As long as the premutation group was in some way compared with some control group, these articles were included because they likely represent an unbiased measurement of premutation phenotypes.

Third, neuropsychological measures were classified into specific cognitive domains to present the results in a coherent manner. However, the classification of several of the measures was difficult given the multiplicity of domains they assess. The authors have attempted to address this issue by providing the reader with the names of the specific tasks utilized by each study presented here.

Finally, several of the retrieved articles contained overlapping samples. To avoid reporting more than once on the same subjects, findings from the most recent publication were reported, unless different phenotype assessments were used.

To compare the magnitude of statistically significant results across studies, effect sizes were provided or calculated using reported data when appropriate. If a correlation was calculated in the study, the corresponding $r$ value is provided. According to Cohen's, $r$ values of $0.1,0.3$, and 0.5 are considered small, medium, and large effects, respectively. ${ }^{27}$ If two groups were compared in an analysis, the reported mean scores and standard deviations were used to calculate Cohen's $d$, where values of $0.2,0.5$, and 0.8 are considered small, medium, and large effects, respectively. ${ }^{27}$ Where a multiple regression was performed, Cohen's $f^{2}$ has been calculated using the reported squared multiple correlation $\left(R^{2}\right)$ for the independent variable tested. ${ }^{27}$ Here, values of $0.02,0.15$, and 0.35 are considered small, medium, and large effects, respectively. ${ }^{27}$ For $\chi^{2}$ tests to compare frequencies of diagnoses between groups, Cramer's $\phi$ was calculated. For $2 \times 2$ tables, as used in the analyses summarized here, this value will be the same as Cohen's $\omega$, where values of $0.10,0.30,0.50$ are considered small, medium, and large effects, respectively. ${ }^{27}$

\section{RESULTS}

In total, 16 studies were included in this review. In an attempt to clearly summarize results, measures used in each study were categorized into five broad cognitive and emotional categories general intelligence, memory, executive functioning, spatial abilities, and psychiatric phenotypes. Several measures were difficult to categorize because the functions they were designed to measure might overlap two or more cognitive processes, but every effort was made to pick the most appropriate category. Table 1 lists the abbreviations for the measures used, and Tables 2-6 summarize the sample groups and results for each category of measures. Results for analyses on males and females are presented separately.

\section{Females}

\section{General intelligence (Table 2)}

The most commonly used measure of overall cognitive functioning in the studies reviewed here was the Weschler Adult Intelligence Scale. This widely used test provides a Full Scale IQ (FSIQ), a Verbal IQ (VIQ), and a Performance IQ (PIQ). One of the most common approaches among these studies has been to ascertain women with the premutation and compare the mean score of this group to the mean score of one or more control groups. Of the studies that evaluated women, none detected a significant difference in FSIQ, PIQ, or VIQ scores between groups ${ }^{13,28-31}$ with the exception of Allen et al. ${ }^{32}$ They reported a significantly lower VIQ mean score for premutation carriers compared with noncarriers, although repeat length only explained $4 \%$ of the variance. ${ }^{32}$

The Weschler Adult Intelligence Scale also provides individual subtest scores. Although the subscales are part of an intelligence battery, individually they are not measures of overall intelligence but rather specific factors of intelligence. Scores on these subtests have been compared between groups of controls and premutation carriers. Several studies have found no signif- 
Table 1. Abbreviations for assessment tools used in reviewed studies

\begin{tabular}{|c|c|}
\hline \multicolumn{2}{|c|}{ Neuropsychological assessments } \\
\hline CBT & Corsi's Block-Tapping test \\
\hline CNT & Contingency naming test \\
\hline HNTLA & Hiskey-Nebraska test of learning aptitude \\
\hline HRD & Hebb's recurring digits \\
\hline JLO & Judgement of line orientation \\
\hline ROF & Rey Osterrieth figure \\
\hline RRT & Reverse reaction time test \\
\hline SCWT & Stroop color word test \\
\hline $\mathrm{TOH}$ & Tower of Hanoi \\
\hline TMT & Trail making test \\
\hline VFT & Verbal fluency test \\
\hline WAIS-III & Wechsler adult intelligence scale-III \\
\hline WAIS-R & Wechsler adult intelligence scale-revised \\
\hline WCST & Wisconsin card sorting task \\
\hline WJ-R & Woodcock-Johnson revised \\
\hline WMS-R & Wechsler memory scale-revised \\
\hline WRAT-3 & Wide range achievement test-3 \\
\hline \multicolumn{2}{|c|}{ Neurobehavior assessments } \\
\hline BPRS & Brief psychiatric rating scale \\
\hline $\mathrm{CS}$ & Chapman scales \\
\hline DIGS & Diagnostic interview for genetics studies \\
\hline HSCL-90 & Hopkins symptoms checklist \\
\hline SADS-L & $\begin{array}{l}\text { Schedule for affective disorders and Schizophrenia- } \\
\text { lifetime version }\end{array}$ \\
\hline SIDP & Structured interview for DSM-III personality \\
\hline SIS & Structured interview for Schizotypy \\
\hline MMPI-2 & Minnesota multiphasic personality inventory-2 \\
\hline NEO-PI & NEO personality inventory \\
\hline PDE & Personality disorder examination \\
\hline PSRS & Psychotic spectrum rating scale \\
\hline SCL-90-R & Symptom checklist- 90 revised \\
\hline
\end{tabular}

icant differences in mean scores on individual subtests between premutation carriers and controls, ${ }^{28,29}$ whereas Franke et al. ${ }^{33}$ found that the premutation carriers scored significantly lower for Vocabulary, Arithmetic, Verbal Comprehension, and Object Assembly.

Using the Wide Range Achievement Test, a measure of academic achievement, Lachiewicz et al. ${ }^{34}$ reported that premutation carriers scored significantly lower than standardized norms on the Arithmetic scale but not on the Reading or Spelling scales.

Another common approach to analyze the impact of carrying the premutation on cognitive functioning has been to examine linear relationships with repeat length and cognitive scores. Although most studies have noted no significant correlation between repeat length and IQ scores $28,29,35,36$ or cognitive subscale scores, ${ }^{28,29,33}$ two studies did detect significant correlations. Allen et al. ${ }^{32}$ detected a significant linear association between VIQ and both repeat length and transcript level in an analysis that included both carriers and noncarriers. Lachiewicz et al. ${ }^{34}$ noted a significant positive correlation between repeat length and Wide Range Achievement Test Arithmetic scores among women. This suggests that Arithmetic subscores increased with repeat length, although, as a whole, the premutation group scored significantly below the standardized norm. This preliminary finding suggests that women with higher repeat premutation alleles may be less affected than those with smaller repeat premutation alleles. However, the authors emphasize the need to confirm these unexpected results in an independent sample because of the limited range of premutation alleles among participants.

\section{Memory (Table 3)}

No significant differences in memory function between premutation carriers and noncarriers were detected in studies reviewed here. Thompson et al. ${ }^{31}$ had a sample of 12 carriers and found that the mean score for the group for verbal memory subscales of the Wechsler Memory Scale-Revised were within the average range. Using other measures of memory, Franke et al. ${ }^{33}$ compared two groups of women with a premutation (65 carriers who were mothers of children with FXS, and 12 carriers without a child with FXS) to two control groups (18 noncarrier siblings of the carrier mothers, and 39 noncarrier mothers of children with autism). No significant differences in mean scores were detected between the premutation groups and control groups. In addition, no significant correlations between repeat length and memory score were detected. Finally, Bennetto et al. ${ }^{13}$ detected no significant differences in mean scores for verbal or visual memory between groups of 96 carriers and 37 noncarrier controls from families with a history of FXS.

\section{Executive function (Table 4)}

None of the studies reviewed here detected any deficits in executive functioning among premutation carriers. Comparing executive function scores between premutation carriers and noncarriers, four studies found no significant mean score differences between groups. ${ }^{13,30,31,33}$ In addition, Franke et al. ${ }^{33}$ found no significant correlation between repeat length and test scores.

\section{Spatial ability (Table 5)}

No deficits were detected in any of the studies using measures of visual/spatial skills, visual/motor skills, visual-spatial perception, and/or visual-spatial organization. ${ }^{13,30,31}$ Comparing carriers with noncarriers, no significant group mean score differences were detected. ${ }^{13,30}$ In addition, Thompson et al. ${ }^{31}$ determined that the mean score of a group of 12 premutation carriers was within the normal range. None of these studies analyzed the correlation of repeat length with spatial ability scores.

\section{Neuropsychiatric symptoms (Table 6)}

Using combinations of neuropsychiatric interviews and behavioral questionnaires, three studies reviewed here detected no significant increased risk for emotional morbidity among carriers of the premutation when compared with noncarrier controls or any significant correlations with repeat length and neurobehavior variables. ${ }^{30,37,38}$ Reiss et al. ${ }^{30}$ did find an increased rate 
Table 2. Summary of findings: general intelligence assessment in females and males

\begin{tabular}{|c|c|c|c|}
\hline $\begin{array}{l}\text { Article } \\
\text { citation }\end{array}$ & Study group(s) ${ }^{a}$ & $\begin{array}{l}\text { Comparison } \\
\text { group }(\mathrm{s})^{a}\end{array}$ & Ascertainment \\
\hline \multicolumn{4}{|l|}{ Females } \\
\hline $\begin{array}{l}\text { Reiss } \\
\quad \text { et } \text { al. }^{30}\end{array}$ & $\begin{array}{l}34 \text { PM, with FXS } \\
\text { child (age: } 39.7 \\
\pm 7.3 \text { ) }\end{array}$ & $\begin{array}{l}41 \mathrm{NC} \text {, with DD } \\
\text { child (age: } 39.0 \\
\pm 6.6 \text { ) }\end{array}$ & $\begin{array}{l}\text { Cytogenetic } \\
\text { records of FXS } \\
\text { relative }\end{array}$ \\
\hline $\begin{array}{l}\text { Thompson } \\
\text { et al. }{ }^{31^{c}}\end{array}$ & $\begin{array}{l}5 \mathrm{FM}, 12 \mathrm{PM} \text { (age } \\
\text { range, 20-49) }\end{array}$ & $\begin{array}{l}\text { Normative sample } \\
\text { to determine } \\
\text { clinical range }\end{array}$ & FXS child in clin \\
\hline $\begin{array}{l}\text { Allingham- } \\
\text { Hawkins } \\
\text { et al. }{ }^{28}\end{array}$ & $\begin{array}{l}14 \text { PM (age range, } \\
\text { 30-65) }\end{array}$ & $\begin{array}{l}\text { Normative sample } \\
\text { to determine } \\
\text { clinical range }\end{array}$ & FXS families \\
\hline \multirow[t]{3}{*}{$\begin{array}{l}\text { Franke } \\
\quad \text { et al. }{ }^{35 d}\end{array}$} & $\begin{array}{l}13 \text { FM, with FXS } \\
\text { child (age: } 35.9 \\
\pm 10.0)\end{array}$ & $\begin{array}{l}18 \mathrm{NC} \text {, siblings of } \\
\text { FXS mothers } \\
\text { (age: } 31.7 \pm \\
12.1 \text { ) }\end{array}$ & $\begin{array}{l}\text { Self-help groups } \\
\text { and genetic } \\
\text { counseling } \\
\text { services }\end{array}$ \\
\hline & $\begin{array}{l}61 \text { PM, with FXS } \\
\text { child (age: } 39.5 \\
\pm 9.8)\end{array}$ & $\begin{array}{l}42 \mathrm{NC} \text {, with } \\
\text { autistic child } \\
\text { (age: } 47.6 \pm \\
7.8 \text { ) }\end{array}$ & \\
\hline & $\begin{array}{l}17 \text { PM, without } \\
\text { FXS child (age: } \\
40.1 \pm 15.0)\end{array}$ & & \\
\hline $\begin{array}{l}\text { Franke } \\
\quad \text { et al. }{ }^{33 d}\end{array}$ & $\begin{array}{l}11 \text { FM, with FXS } \\
\text { child (age: } 35.7 \\
\pm 10.9)\end{array}$ & $\begin{array}{l}18 \mathrm{NC} \text {, siblings of } \\
\text { mothers (age: } \\
32.0 \pm 11.9 \text { ) }\end{array}$ & $\begin{array}{l}\text { Self-help groups } \\
\text { and genetic } \\
\text { counseling } \\
\text { services }\end{array}$ \\
\hline
\end{tabular}

WAIS-R Mean scores of PM mothers significantly lower than scores for NC groups for vocabulary (Cohen's $d$ $=0.55, P<0.01$ ), arithmetic (Cohen's $d=0.73$, $P<0.01$ ), verbal comprehension (Cohen's $d=$ $0.54, P, 0.01$ ), and object assembly (Cohen's $d=$ $0.69, P<0.01)$

No significant differences for information, digit span, similarities, digit symbol, picture completion, block design, or picture arrangement subtests

65 PM, with FXS child (age: 39.8 $\pm 9.4)$

14 PM, without FXS child (age: $34.9 \pm 12.9)$

\section{Johnston 85 PM} et al. ${ }^{29}$

Bennetto et al. ${ }^{13 e}$

(66 with $<100$ repeats;

(19 with $>100$ repeats) (age range 30-51)

32 FM, 96 PM
$39 \mathrm{NC}$, with autistic child (age: $47.5 \pm$ 8.6)
Normative sample Child with FXS to determine clinical range (age range, 1845)
$37 \mathrm{NC}$, from FXS families, (age range, $18-45)$ as relatives of FXS individual

Scores for PM mothers and PM nonmothers not significantly different

Scores not significantly correlated with repeat length

WAIS-III All PM mean scores for FSIQ, VIQ, PIQ, vocabulary, information, comprehension, arithmetic, digit span, picture arrangement, picture completion, block design, matrix reasoning, coding or symbol search within the normal range

Two PM groups not different in scores

No correlation between IQ and repeat length

Children's hospital WAIS-R PM scores not significantly different from controls for
FSIQ, VIQ, or PIQ 
Table 2. Continued

\begin{tabular}{|c|c|c|c|c|c|}
\hline $\begin{array}{l}\text { Article } \\
\text { citation }\end{array}$ & Study group $(\mathrm{s})^{a}$ & $\begin{array}{l}\text { Comparison } \\
\operatorname{group}(\mathrm{s})^{a}\end{array}$ & Ascertainment & Measures $^{b}$ & Results \\
\hline $\begin{array}{l}\text { Allen } \\
\quad \text { et al. }{ }^{32}\end{array}$ & $\begin{array}{l}84 \text { PM (age range, } \\
18-50)\end{array}$ & $\begin{array}{l}74 \mathrm{NC} \text { (age range, } \\
18-50)\end{array}$ & $\begin{array}{l}\text { General population } \\
\text { and FXS } \\
\text { families }\end{array}$ & WAIS-III & $\begin{array}{l}\text { PM scores not significantly different than NC for } \\
\text { FSIQ and PIQ, but PM did score significantly lower } \\
\text { than NC for VIQ (Cohen's } d=0.44, P=0.05 \text { ) } \\
\text { Significant negative linear association between VIQ } \\
\text { and repeat length (Cohen's } f^{2}=0.04, P=0.01 \text { ) } \\
\text { and mRNA levels (Cohen's } f^{2}=0.02, P=0.04 \text { ) } \\
\text { Significant linear associations between repeat length } \\
\text { and VIQ subtest scores for verbal comprehension } \\
\text { index (Cohen's } f^{2}=0.03, P=0.01 \text { ), similarities } \\
\text { (Cohen's } f^{2}=0.03, P=0.01 \text { ), information } \\
\text { (Cohen's } f^{2}=0.03, P=0.01 \text { ), working memory } \\
\left.\text { index (Cohen's } f^{2}=0.02, P=0.05\right) \text {, and letter- } \\
\text { number sequencing (Cohen's } f^{2}=0.02, P=0.04 \text { ) } \\
\text { but not vocabulary, arithmetic, or digit span }\end{array}$ \\
\hline $\begin{array}{l}\text { Hessl } \\
\quad \text { et al. }{ }^{36}\end{array}$ & $\begin{array}{l}122 \text { PM, without } \\
\text { FXTAS (age: } \\
49.9 \pm 12.8 \text { ) } \\
22 \text { PM, with } \\
\text { FXTAS (age: } \\
63.1 \pm 12.8 \text { ) }\end{array}$ & $\begin{array}{l}\text { PM group not } \\
\text { compared with } \\
\text { a NC group or } \\
\text { normative } \\
\text { sample }\end{array}$ & FXS families & WAIS-III & $\begin{array}{l}\text { Multiple regression analysis detected no significant } \\
\text { effects of repeat length, protein, or transcript on } \\
\text { FSIQ }\end{array}$ \\
\hline $\begin{array}{l}\text { Lachiewicz } \\
\text { et al. }{ }^{34}\end{array}$ & $\begin{array}{l}8 \text { FM (age: } 32.1 \pm \\
12.8 \text { ) }\end{array}$ & $\begin{array}{l}\text { Normative sample } \\
\text { to determine } \\
\text { clinical range }\end{array}$ & FXS clinic & WRAT-3 & $\begin{array}{l}\text { PM scored significantly lower than standardized norms } \\
\text { for arithmetic (Cohen's } d=0.73, P<0.01 \text { ) but not } \\
\text { reading ability or spelling skills } \\
\text { Among PM, significant correlation between repeat } \\
\quad \text { length and arithmetic scores detected }(r=0.48 \text {, } \\
\quad P<0.01)\end{array}$ \\
\hline Males & & & & & \\
\hline $\begin{array}{l}\text { Allen } \\
\quad \text { et al. }{ }^{32}\end{array}$ & $\begin{array}{l}19 \text { PM (age range, } \\
18-50)\end{array}$ & $\begin{array}{l}24 \mathrm{NC} \text { (age range, } \\
18-50)\end{array}$ & $\begin{array}{l}\text { General population } \\
\text { and FXS } \\
\text { families }\end{array}$ & WAIS-III & PM scores not significantly different from NC \\
\hline $\begin{array}{l}\text { Hessl } \\
\quad \text { et al. }{ }^{36}\end{array}$ & $\begin{array}{l}26 \text { PM, without } \\
\text { FXTAS (age: } \\
56.6 \pm 12.5 \text { ) } \\
42 \text { PM, with } \\
\text { FXTAS (age: } \\
67.1 \pm 7.1 \text { ) }\end{array}$ & $\begin{array}{l}\text { PM group not } \\
\text { compared with } \\
\text { a NC group or } \\
\text { normative } \\
\text { sample }\end{array}$ & FXS families & WAIS-III & $\begin{array}{l}\text { Significant negative correlation between FSIQ and } \\
\text { repeat length }(r=-0.32, P<0.05) \text { among all PM } \\
\text { males but not } F M R 1 \text { mRNA or FMRP }\end{array}$ \\
\hline
\end{tabular}

${ }^{a}$ Where available, either mean age ( \pm SD) or age range of group presented.

${ }^{b}$ Measure names and abbreviations are presented in Table 1.

${ }^{c}$ Object of study was to analyze neuropsychological profile of FM carriers.

${ }^{d}$ Franke et al. ${ }^{33,35,50}$ contain overlapping subject populations. Franke et al. ${ }^{35,50}$ analyzed repeat length effects on FSIQ and found no significant effects. Only the results of Franke et al. ${ }^{35}$ are shown. Franke et al. ${ }^{33}$ analyzed PIQ and VIQ subscales, so these results are shown also.

${ }^{e}$ Subject groups overlap with Sobesky et al., ${ }^{37,38,47}$ Riddle et al., ${ }^{48}$ and Simon et al. ${ }^{49}$ All six articles looked at WAIS-R scores and, with the exception of Simon et al. ${ }^{49}$, found no mean score differences for FSIQ, VIQ, or PIQ. In addition, the Sobesky et al. ${ }^{37,38}$ did not detect a correlation with repeat length and IQ score. Only results of the most recent article, Bennetto et al. ${ }^{13}$ are shown here.

FM, full mutation; PM, premutation; NC, noncarrier; FSIQ, full scale IQ; PIQ, performance IQ; VIQ, verbal IQ; DD, developmentally disabled; FXS, fragile X syndrome; FXTAS, Fragile X-association tremor/ataxia syndrome.

of stereotypy-habit disorder in the group of premutation carriers who were mothers of children with FXS, but concluded that the presence of this behavior in the absence of other psychiatric issues did not indicate a clinical mental health problem.

Thompson et $a .^{31}$ reported on a group of 12 premutation carriers and noted that although they did not have an increased rate of schizotypal features, the group had a higher rate of depression (75\%) than would be expected in the general population. However, this result is compromised by the clinical ascertainment methods of the study and the lack of a compar- ison group. In addition, comparison with the general population rates of depression may not be appropriate, as mothers of special needs children are known to have increased rates of depression. ${ }^{39}$ In support of this finding, Franke et al. ${ }^{35}$ found a significantly increased frequency of anxiety and depression disorders among a group of 61 premutation carriers, who were mothers of children with FXS compared with 42 noncarriers who were mothers of children with autism and with 18 noncarrier family controls. However, no significant differences were detected between 17 premutation carriers who were not mothers 
Table 3. Summary of findings: memory assessment in females

\begin{tabular}{|c|c|c|c|c|c|}
\hline $\begin{array}{l}\text { Article } \\
\text { citation }\end{array}$ & Study group $(\mathrm{s})^{a}$ & Comparison group $(\mathrm{s})^{a}$ & Ascertainment & Measures $^{b}$ & Results \\
\hline $\begin{array}{l}\text { Thompson } \\
\text { et al. }{ }^{31^{c}}\end{array}$ & $\begin{array}{l}5 \text { FM, } 12 \text { PM } \\
\text { (age range, 20-49) }\end{array}$ & $\begin{array}{l}\text { Normative sample to } \\
\text { determine clinical } \\
\text { range }\end{array}$ & FXS child in clinic & WMS-R & $\begin{array}{l}\text { PM scored within average range for } \\
\text { verbal memory }\end{array}$ \\
\hline \multirow[t]{4}{*}{$\begin{array}{l}\text { Franke } \\
\text { et al. }{ }^{33}\end{array}$} & $\begin{array}{l}11 \text { FM, with FXS child } \\
\text { (age: } 35.7 \pm 10.9 \text { ) }\end{array}$ & $\begin{array}{l}18 \text { NC, siblings of FXS } \\
\text { mothers, } \\
\text { (age: } 32.0 \pm 11.9 \text { ) }\end{array}$ & $\begin{array}{l}\text { Self-help groups and } \\
\text { genetic counseling } \\
\text { services }\end{array}$ & HRD & $\begin{array}{l}\text { No significant differences between } \\
\text { mean scores for PM and NC groups } \\
\text { for memory tests }\end{array}$ \\
\hline & & & & CBT & $\begin{array}{l}\text { No significant correlations between } \\
\text { scores and repeat length }\end{array}$ \\
\hline & $\begin{array}{l}65 \text { PM, with FXS child } \\
\text { (age: } 39.8 \pm 9.4 \text { ) }\end{array}$ & $\begin{array}{l}39 \text { NC, with autistic } \\
\text { child (age: } 47.5 \pm \\
\text { 8.6) }\end{array}$ & & & \\
\hline & $\begin{array}{l}14 \text { PM, without FXS } \\
\text { child (age: } 34.9 \pm \\
12.9)\end{array}$ & & & & \\
\hline $\begin{array}{l}\text { Bennetto } \\
\text { et al. }{ }^{13}\end{array}$ & $\begin{array}{l}32 \mathrm{FM}, 96 \mathrm{PM} \text { (age } \\
\text { range, 18-45) }\end{array}$ & $\begin{array}{l}37 \mathrm{NC} \text {, from FXS } \\
\text { families }\end{array}$ & $\begin{array}{l}\text { Children's hospital as } \\
\text { relatives of FXS } \\
\text { individual }\end{array}$ & WMS-R & $\begin{array}{l}\text { No significant differences in scores } \\
\text { between PM and NC, for both verbal } \\
\text { and visual memory }\end{array}$ \\
\hline $\begin{array}{l}{ }^{a} \text { Where avai } \\
{ }^{b} \text { Measure na } \\
{ }^{c} \text { Object of st } \\
\text { FM, full mu }\end{array}$ & $\begin{array}{l}\text { able, either mean age ( } \pm \mathrm{SD}) \\
\text { nes and abbreviations are pre } \\
\text { dy was to analyze neuropsyc } \\
\text { ation; } \mathrm{PM} \text {, premutation; } \mathrm{NC},\end{array}$ & $\begin{array}{l}r \text { age range of group presente } \\
\text { nted in Table } 1 . \\
\text { logical profile of FM carriers }\end{array}$ & & & \\
\hline
\end{tabular}

Table 4. Summary of findings: executive function assessment in females

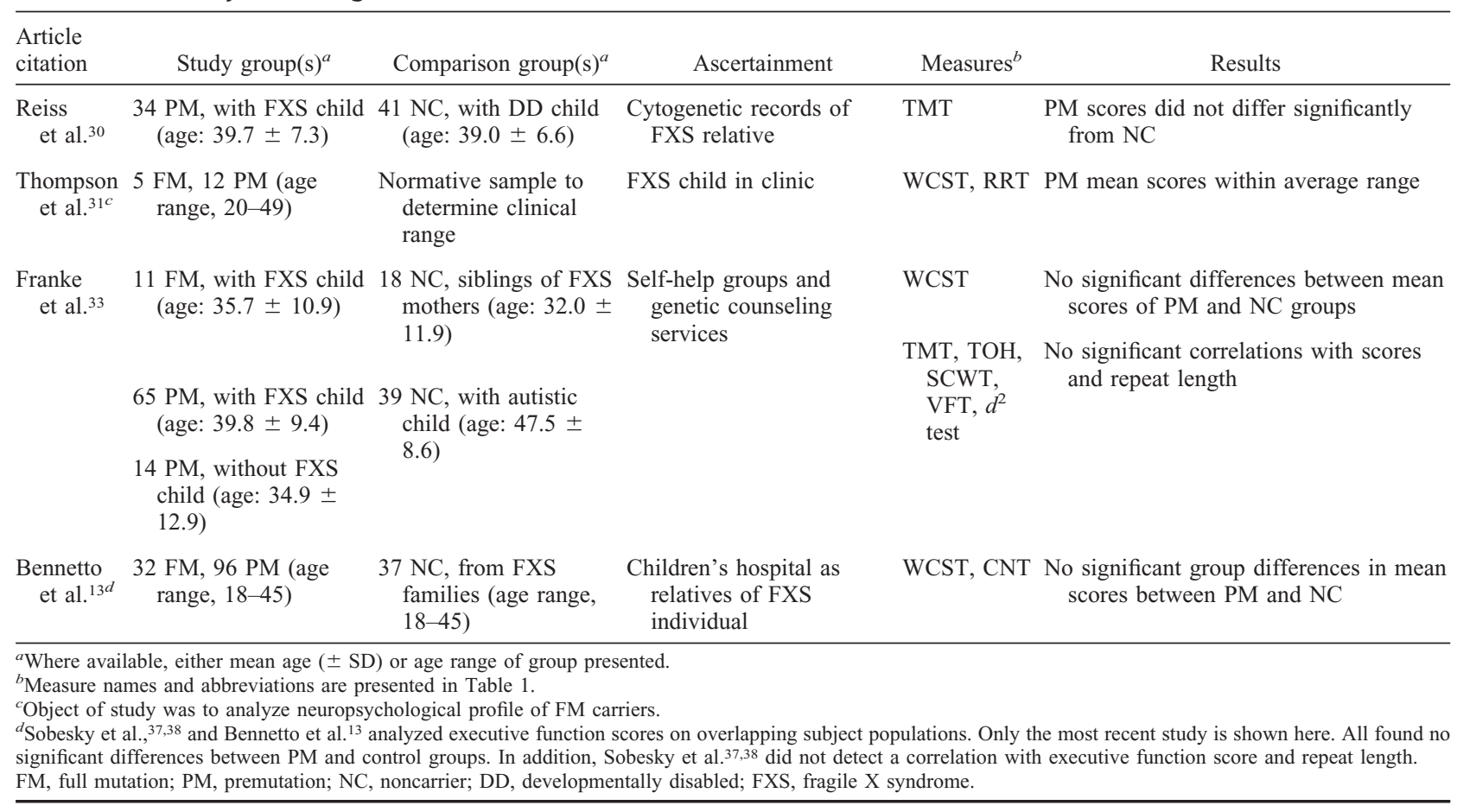

of children with FXS and the control groups, indicating that the emotional morbidity could be due to raising a child with FXS. The authors attempted to address this by determining the mean age at onset of the mood disorders/psychiatric diseases. Onset tended to be earlier than the mean age of the mother when their child was diagnosed with FXS suggesting that the disorders were most likely unrelated to raising a child with special needs.
Johnston et al. ${ }^{29}$ studied carriers separated into two groups based on repeat length ( 66 women with $<100$ repeats and 19 women with more than 100 repeats). Results indicated that the group with the larger repeat sizes had significantly higher mean scores for depression and interpersonal sensitivity but not anxiety or overall symptomology. Results also showed a significant positive correlation with repeat length and depression scores. 
Table 5. Summary of findings: spatial ability assessment in females

\begin{tabular}{|c|c|c|c|c|c|}
\hline $\begin{array}{l}\text { Article } \\
\text { citation }\end{array}$ & Study group $(s)^{a}$ & $\begin{array}{l}\text { Comparison } \\
\operatorname{group}(\mathrm{s})^{a}\end{array}$ & Ascertainment & Measures $^{b}$ & Results \\
\hline $\begin{array}{l}\text { Reiss } \\
\quad \text { et al. }{ }^{30}\end{array}$ & $\begin{array}{l}34 \text { PM, with FXS } \\
\text { child (age: } 39.7 \\
\pm 7.3 \text { ) }\end{array}$ & $\begin{array}{l}41 \mathrm{NC} \text {, with DD } \\
\text { child (age: } \\
39.0 \pm 6.6)\end{array}$ & $\begin{array}{l}\text { Cytogenetic records } \\
\text { of FXS relative }\end{array}$ & HNTLA & $\begin{array}{l}\text { No significant group differences in mean scores for } \\
\text { block construction and spatial reasoning tasks } \\
\text { between PM and NC }\end{array}$ \\
\hline $\begin{array}{l}\text { Thompson } \\
\text { et al. }{ }^{31^{c}}\end{array}$ & $\begin{array}{l}5 \text { FM, } 12 \text { PM, } \\
\text { (age range, 20- } \\
\text { 49) }\end{array}$ & $\begin{array}{l}\text { Normative } \\
\text { sample to } \\
\text { determine } \\
\text { clinical range }\end{array}$ & FXS child in clinic & JLO, ROF & $\begin{array}{l}\text { Mean PM scores within average range for visual- } \\
\text { spatial perception and organization }\end{array}$ \\
\hline $\begin{array}{r}\text { Bennetto } \\
\text { et al. }{ }^{13}\end{array}$ & $\begin{array}{l}32 \text { FM, } 96 \text { PM, } \\
\text { (age range, 18- } \\
45 \text { ) }\end{array}$ & $\begin{array}{l}37 \mathrm{NC} \text {, from } \\
\text { FXS families, } \\
\text { (age range, } \\
18-45)\end{array}$ & $\begin{array}{l}\text { Children's hospital as } \\
\text { relatives of FXS } \\
\text { individual }\end{array}$ & WJ-R & $\begin{array}{l}\text { No significant differences in means scores between } \\
\text { PM and NC for spatial relations subtest }\end{array}$ \\
\hline \multicolumn{6}{|c|}{$\begin{array}{l}\left.{ }^{a} \text { Where available, either mean age ( } \pm \mathrm{SD}\right) \text { or age range of group presented. } \\
{ }^{b} \text { Measure names and abbreviations are presented in Table } 1 . \\
{ }^{c} \text { Object of study was to analyze neuropsychological profile of FM carriers. } \\
\text { FM, full mutation; PM, premutation; NC, noncarrier; DD, developmentally disabled; FXS, fragile X syndrome. }\end{array}$} \\
\hline
\end{tabular}

However, there was not a control group and the tests were not adjusted for raising a child with FXS.

The most recent study to analyze emotional morbidity among premutation carriers is Hessl et al. ${ }^{36}$ Women with the premutation with and without symptoms of FXTAS were assessed for psychiatric symptomology using a symptom checklist (SCL-90R). Those without symptoms of FXTAS displayed a significantly increased risk of emotional morbidity compared with normative controls. No significant correlations with repeat length, FMR1 mRNA levels, or protein levels were noted among premutation carriers.

\section{Males}

\section{General intelligence (Table 2)}

Allen et al. ${ }^{32}$ analyzed cognitive functioning among premutation carriers and found no significant differences in FSIQ, PIQ, or VIQ scores when compared with noncarrier controls, although sample sizes were small. Hessl et al. ${ }^{36}$ noted a significant negative correlation between IQ score and repeat length among premutation carriers but did not detect significant correlations between IQ scores and FMRI mRNA or FMRP levels. Unfortunately, the premutation group in the study of Hessl et al. ${ }^{36}$ included both men with and without FXTAS symptoms. Therefore, no conclusions can be made about the neurocognitive functioning of premutation carriers outside the context of FXTAS.

\section{Neuropsychiatric symptoms (Table 6)}

The only study to analyze emotional morbidity among men with the premutation is Hessl et al. ${ }^{36}$ Carriers with and without symptoms of FXTAS were assessed for psychiatric symptomology using the SCL-90-R symptom checklist. Premutation carriers without symptoms of FXTAS displayed a significantly increased risk of emotional morbidity compared with normative controls. Further, the severity of symptoms was significantly correlated with FMR1 mRNA levels but not repeat length or protein level. For most scales, the strongest correlation was noted among men who carried the premutation but did not have FXTAS.

\section{DISCUSSION}

Since the discovery of the dynamic repeat sequence mutation in the FMR1 gene, there has been interest in understanding the influence of this repeat expansion on neuropsychological and neurobehavioral outcomes. This interest was fueled by the significant discovery of FXTAS, a premutation-associated lateonset neurodegenerative disorder. ${ }^{19,20}$ For premutation carriers aged 18-50 years, many studies have been performed to understand the genotype/phenotype correlations. These results have been conflicting.

The primary objective of this report was to review the current literature and identify studies on the neuropsychological phenotype of adults who carry the FMR 1 premutation that fit strict criteria based on participant eligibility, molecular diagnosis of the premutation, and study design. On the basis of these studies, we asked: Does a pattern of neurocognitive and neurobehavioral deficits emerge in premutation carriers not affected by FXTAS? The primary finding is that no specific pattern of neurocognitive or neurobehavioral deficits emerges. For females, none of the studies reviewed here reported deficits in executive functioning, memory, or spatial ability among carriers of premutation alleles. Importantly, no studies that fit our strict criteria for inclusion were available to assess these domains among males. In addition, no deficits were noted in verbal functioning among females (Table 2) with the exception of two studies: one identified deficits of medium effect size, ${ }^{33}$ whereas the other found only those of small effect size. ${ }^{32}$ Similarly, other deficits detected among neuropsychological domains identified in single studies were of small to medium effect sizes (Table 2).

In regard to neurobehavior phenotypes, some studies suggest an increased risk of emotional morbidity, ${ }^{29,31,35,36}$ particularly for depression and anxiety disorders, compared with controls, whereas other studies indicate a lack of phenotype among premutation carriers ${ }^{30,31}$ (Table 6). The difficulty to determine whether depression and anxiety results from the emotional toll of being a carrier and having a child with FXS or results from the effect of the premutation allele is noted by most of these studies. For example, Franke et al. ${ }^{35}$ examined the onset of depression among women with respect to the diagnosis of their child with FXS. However, it may be necessary to conduct prospective studies among those at risk for carrying the 
Table 6. Summary of findings: neurobehavior assessment in females and males

\begin{tabular}{|c|c|c|c|c|c|}
\hline $\begin{array}{l}\text { Article } \\
\text { citation }\end{array}$ & Study group $(\mathrm{s})^{a}$ & $\begin{array}{l}\text { Comparison } \\
\operatorname{group}(\mathrm{s})^{a}\end{array}$ & Ascertainment & Measures $^{b}$ & Results \\
\hline
\end{tabular}

Females

Reiss et al. ${ }^{30}$

34 PM, with FXS $41 \mathrm{NC}$, with child (age: 39.7 DD child $\pm 7.3) \quad$ (age: 39.0 $\pm 6.6)$

Sobesky 21 FM, 64 PM, (age range, $18-45)$

$61 \mathrm{NC}$, with DD child

Records from FXS child at a children's hospital

$25 \mathrm{NC}$, from

FXS

families

(age range,

18-45)

Thompson

5 FM, 12 PM,

Normative sample to determine

clinical range

Sobesky et al. ${ }^{37 c, d}$

29 FM, 92 PM,

FXS child in clinic SADS-L (age range,

$35 \mathrm{NC}$, from FXS families (age range, 18-45)

Franke et al. ${ }^{35 e}$

13 FM, with FXS $18 \mathrm{NC}$, child (age: 35.9 $\pm 10.0)$

siblings FXS mothers (age: 31.7 $\pm 12.1)$

61 PM, with FXS 42 NC, with child (age: 39.5 autistic $\pm 9.8) \quad$ child (age:

17 PM, with FXS $47.6 \pm$ child (age: 40.1 $\pm 15.0)$

Johnston 85 PM (66 with Normative et al. ${ }^{29}<100$ repeats; sample to 19 with $>100 \quad$ determine repeats) (age clinical range, 30-51) range

child at a

children's

hospital

MMPI-2

CS
Cytogenetic records Modified SADS-L No significant group differences in symptom severity or of FXS relative interview, psychiatric diagnoses of major depression, dysthymia, Partial SIDP, bipolar disorder, psychotic disorder, social phobia, BPRS, PSRS, generalized anxiety disorder, schizotypal personality HSCL-90, NEO-PI disorder, avoidant personality disorder, psychiatric disturbances, and personality traits

Stereotypy-habit behavior more common in $\operatorname{PM}(\Phi=$ $0.30, P<0.05$ )

No significant association between repeat length and behavior

SADS-L interview Among PM, no significant increase in diagnostic rates of major depression syndrome, dysthymia, social phobia, or generalized anxiety disorder when compared with controls.

No significant correlation between repeat length and neurobehavior variables

PM did not show increased rates of schizotypal features but had higher rates of depression (75\%) than would be expected in the general population

No significant differences in emotional traits between $\mathrm{PM}$ and $\mathrm{NC}$

No significant correlation with repeat length and scores

PM mothers had significantly increased frequency of anxiety disorders, including social phobia, compared with mothers of autistic children $(\Phi=0.18$, $P=0.05)$ and PM siblings without FXS children $(\Phi=0.25, P=0.02)$

PM mothers diagnosed with major depressive episodes more often compared with nonmother PM females $(P$ $=0.03)$ and family controls $(P<0.01)^{f}$

No significant differences between PM mothers and NC for psychoses, substance abuse, or personality disorders

Child with FXS SCL-90-R

Mean scores within normal range

Significant positive correlation between repeat length and depression after adjusting for age $(r=0.22, P=$ $0.04)$

Higher repeat group had significantly higher mean score for depression (Cohen's $d=0.50, P=0.04$ ) and interpersonal sensitivity (Cohen's $d=0.56, P$ $=0.02$ ) but not anxiety or global severity of symptoms 
Table 6. Continued

\begin{tabular}{|c|c|c|c|c|c|}
\hline $\begin{array}{l}\text { Article } \\
\text { citation }\end{array}$ & Study group $(\mathrm{s})^{a}$ & 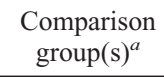 & Ascertainment & Measures $^{b}$ & Results \\
\hline \multirow[t]{4}{*}{$\begin{array}{l}\text { Hessl } \\
\text { et al. }{ }^{36}\end{array}$} & \multirow[t]{2}{*}{$\begin{array}{l}122 \text { PM, without } \\
\text { FXTAS (age: } \\
49.9 \pm 12.8)\end{array}$} & \multirow[t]{4}{*}{$\begin{array}{l}\text { Normative } \\
\text { sample to } \\
\text { determine } \\
\text { clinical } \\
\text { range }\end{array}$} & \multirow[t]{4}{*}{ FXS families } & \multirow[t]{4}{*}{ SCL-90-R } & $\begin{array}{l}\text { PM without symptoms of FXTAS scored significantly higher } \\
\text { on obsessive-compulsive (Cohen's } d=0.32, P<0.01 \text { ), } \\
\text { phobic anxiety (Cohen's } d=0.25, P=0.01 \text { ), and } \\
\text { paranoid ideation (Cohen's } d=0.25, P<0.01 \text { ) scales }\end{array}$ \\
\hline & & & & & $\begin{array}{l}\text { PM with symptoms of FXTAS scored significantly } \\
\text { higher on somatization (Cohen's } d=0.86, P<0.01 \text { ), } \\
\text { obsessive-compulsive (Cohen's } d=1.00, P<0.001 \text { ), } \\
\text { interpersonal sensitivity (Cohen's } d=0.54, \mathrm{p} 0.05 \text { ), } \\
\text { depression (Cohen's } d=0.74, P<0.01 \text { ), } \\
\text { psychoticism (Cohen's } d=0.55, P<0.05 \text { ), and } \\
\text { global severity scales (Cohen's } d=0.71, \mathrm{p} 0.01 \text { ) }\end{array}$ \\
\hline & \multirow[t]{2}{*}{$\begin{array}{l}22 \text { PM, with } \\
\text { FXTAS (age: } \\
63.1 \pm 12.8 \text { ) }\end{array}$} & & & & $\begin{array}{l}\text { Among all PM, no significant correlations with repeat } \\
\text { length, mRNA levels, or protein levels detected for } \\
\text { any scales }\end{array}$ \\
\hline & & & & & $\begin{array}{l}\text { Significant association between } \mathrm{mRNA} \text { level and anxiety } \\
\text { scores for PM with } \mathrm{X} \text { activation ratios less than } 0.5(r \\
=0.57, P<0.001)\end{array}$ \\
\hline
\end{tabular}

Males

$\begin{array}{crrrr}\text { Hessl } & \text { 26 PM, without } & \text { Normative } & \text { FXS families } & \text { SCL-90-R } \\ \text { et al. }{ }^{36} & \text { FXTAS (age: } & \text { sample to } \\ & 56.6 \pm 12.5) & \begin{array}{l}\text { determine } \\ \text { clinical } \\ \text { range }\end{array} & \end{array}$

42 PM, with

FXTAS (age:

$67.1 \pm 7.1)$
PM without symptoms of FXTAS scored significantly higher on obsessive-compulsive (Cohen's $d=0.89, P$ $<0.0001$ ) and psychoticism (Cohen's $d=0.52, P<$ $0.05)$ scales as well as overall symptom severity (Cohen's $d=0.53, P<0.05$ )

PM with symptoms of FXTAS scored significantly higher on somatization (Cohen's $=0.51, P<0.01$ ), obsessive-compulsive (Cohen's $d=0.80, P<$ 0.0001 ), interpersonal sensitivity (Cohen's $d=0.44$, $P<0.01$ ), depression (Cohen's $d=0.68, P<$ 0.001 ), anxiety (Cohen's $d=0.55, P<0.01$ ), phobic anxiety (Cohen's $d=0.57, P<0.01$ ), psychoticism (Cohen's $d=0.47, P, 0.01$ ), and global severity scales (Cohen's $d=0.65, P=0.01$ )

Among all PM, mRNA levels significantly positively correlated with somatization $(r=0.38, P<0.01)$, obsessive-compulsive $(r=0.47, P<0.001)$, interpersonal sensitivity $(r=0.38, P<0.01)$, depression $(r=0.44, P<0.001)$, anxiety $(r=0.41$, $P<0.01)$, hostility $(r=0.42, P<0.01)$, paranoid ideation $(r=0.45, P<0.001)$, psychoticism $(r=$ $0.50, P<0.001)$, global severity index $(r=0.45, P$ $<0.001)$ but not phobic anxiety, with correlation stronger in PM without FXTAS symptoms

Paranoid ideation significantly positively correlated with CGG repeat $(r=0.39, P<0.01)$

No significant correlations with protein level

\footnotetext{
${ }^{a}$ Where available, either mean age $( \pm$ SD) or age range of group presented.

${ }^{b}$ Measure names and abbreviations are presented in Table 1.

${ }^{c}$ Object of study was to analyze neuropsychological profile of FM carriers.

${ }^{d}$ Sobesky et al. ${ }^{37,38,47}$ used overlapping subject populations to analyze neurobehavioral phenotypes. Sobesky et al. ${ }^{38}$ used the SADS-L interview and the MMPI-2, Sobesky et al. ${ }^{47}$ used the SIS interview, and Sobesky et al. ${ }^{37}$ used the MMPI-2 and the SIS interview. SADS-L results are shown from Sobesky et al. ${ }^{38}$ and the most recent MMPI-2 and SIS results are shown from Sobesky et al. ${ }^{37}$

${ }^{e}$ Franke et al. ${ }^{35,50}$ used overlapping subject populations to analyze neurobehavioral phenotypes using the DIGS interview. In addition, Franke et al. ${ }^{35}$ used the PDE and Chapman Scale. The most recent study is shown.

${ }^{f}$ Could not calculate effect sizes based on data provided.

FM, full mutation; PM, premutation; NC, noncarrier; DD, developmentally disabled; FXS, fragile X syndrome; FXTAS, Fragile X-association tremor/ataxia syndrome.
}

premutation, as it is difficult to take into account when the environment of a woman who has a child with behavior problems and other issues associated with FXS begins to become stressful. Irrespective, among those studies that de- tected a phenotype, the largest effect sizes were found by Hessl et al. ${ }^{36}$ for the obsessive-compulsive scale in men and women and for somatization among women. All other effect sizes were small to medium. ${ }^{27}$ 
Although further investigation is certainly warranted, particularly among males, the presence of global cognitive impairment or severe psychiatric morbidity is unlikely based on the effect sizes of the deficits summarized here. However, this conclusion needs to be considered within the context of the criteria we used for including published studies. We used strict inclusion criteria as outlined in the Methods section and excluded studies on those $<18$ years of age and/or $>50$ years of age. As symptoms of FXTAS usually occur after age 50, studies were excluded when they might have unknowingly included men who had symptoms of FXTAS. The exception to this was Hessl et al. ${ }^{36}$ because the subjects were assessed for FXTAS status. Of those studies that were excluded based on this criterion, several had results that are worth noting. Loesch et al. ${ }^{11,40,41}$ in a series of publications reported cognitive deficits and behavioral issues in men and women who carried the premutation whose ages ranged from roughly 5 to 80 . Moore et al. ${ }^{42}$ reported deficits in executive functioning and memory in a sample of 20 men who carried the premutation with a mean age of roughly 53. Finally, Cornish et al. ${ }^{43}$ reported group differences in social cognition between a sample of men who were carriers of the premutation and controls ranging from age 18 to 69 . However, the possibility that these deficits were detected because of the inclusion of subjects affected by FXTAS rather than because of a general impairment associated with premutation alleles cannot be ruled out. The decision to include studies with women over the age of 50 was difficult, particularly because women who are carriers of the premutation are known to be at risk of FXTAS. ${ }^{26}$ However, this risk is much lower than that for male carriers. In addition, women are likely to be less severely affected because of the X-linked nature of FMR1.

The exclusion of publications that included study participants under the age of 18 resulted in the exclusion of the two studies that analyzed the autism spectrum disorders. ${ }^{44,45}$ Autism spectrum disorders have not been assessed directly among younger adult premutation carriers. Although these excluded studies are not included in the body of the review, the possibility that premutation carriers are at an increased risk of autism spectrum disorders cannot be ruled out.

It is important to point out that even with strict criteria for inclusion, several of the studies in this review had methodological weaknesses. Most significantly, the majority of studies have modest sample sizes, limiting the power to detect phenotypes particularly if the effect size is small. In addition, as pointed out by Franke et $a .^{33}$ in their own analysis, the possibility of a statistical difference being detected by chance is worth considering given the number of statistical tests conducted.

The results of several studies are also complicated by a lack of proper controls. For example, the comparison of mean scores of premutation carriers with normative samples is a practice that does not control for ascertainment biases and other complications that inadvertently occur in studies of this type. In the case of fragile X specifically, it does not control for the psychosocial impact of raising a child with FXS. This is an important point, particularly when considering the neurobehavioral domain. Overall, the interpretation and comparison of results across studies is complicated by varying study design, including different ascertainment strategies, phenotype measurement, and definition of a premutation allele. These differences likely contribute to the variable outcomes of the studies.

Lastly, many studies ascertained participants from pediatric and genetic clinics. These participants may not be representative of all carriers of premutation alleles. Socioeconomic status may limit access to these clinics. Further, participation may be influenced by attributes of the phenotypes themselves. For ex- ample, a person struggling with social interaction may be less likely to participate in any studies.

\section{Conclusions and future directions}

The one strong conclusion drawn from this review is that more research is needed, particularly for men. Most studies to date have focused in female carriers as they are more frequent in the population, $1 / 250$ compared with $1 / 1000$ in male carriers. ${ }^{46}$ However, the likelihood of detecting a phenotype among premutation carriers should be higher among men because of the X-linked nature of the gene.

It will be important to limit studies to adult subjects under the age of 50 to distinguish any deficits detected from those associated with the onset of FXTAS. The potential that any phenotypes detected in premutation carriers could constitute early signs of FXTAS is an intriguing one, particularly if these early signs are predictive of clinical outcomes of FXTAS. Identification of such early signs may enable preventative treatments in the future, thus avoiding the significant problems associated with FXTAS. This possibility could best be addressed with longitudinal studies in men who are carriers of the premutation. In addition, studies that analyze associations between FMRP levels and phenotypes could provide evidence on whether these phenotypes share molecular etiology to FXS because of decreased protein levels in higher premutation groups.

In addition, more widespread ascertainment strategies are needed to address issues related to the phenotypes being assessed. For example, cognitive impairments, depression, and issues with social interactions will likely impact personal relationships and/or the ability or choice to conceive and raise a child. Therefore, ascertainment through a child with FXS limits the premutation allele carriers included in the study to those who have been able to maintain a personal relationship and mate. In general, it may be difficult to assess such phenotypes, as they may influence participation in a study. This emphasizes the importance of ascertaining controls in the same manner as cases to minimize the potential bias.

The psychosocial burden of raising a child with FXS is an issue that requires attention in the study design. Several studies have included a control group consisting of mothers of children with special needs. However, those that have a developmentally disabled child might also carry other genetic factors that adversely affect cognitive functioning and psychiatric phenotype. This is likely more pertinent to mothers of children with an unknown etiology for developmental delay, such as autism, rather than for children with a noninherited disorder such as Down syndrome.

Finally, although most studies limit their analyses to phenotype associations with repeat length, the mechanism of central nervous system involvement might better be represented by the use of other molecular measures, including levels of FMRI mRNA and FMRP.

\section{ACKNOWLEDGMENTS}

This work was supported by NIH R01 HD29909 and P30 HD24064. This review is dedicated to Dr. Richard Letz who provided guidance and expertise in our studies of premutationassociated disorders.

\section{REFERENCES}

1. Yu S, Pritchard M, Kremer E, et al. Fragile X genotype characterized by an unstable region of DNA. Science 1991;252:1179-1181.

2. Verkerk AJ, Pieretti M, Sutcliffe JS, et al. Identification of a gene (FMR-1) containing a CGG repeat coincident with a breakpoint cluster region exhibiting length variation in fragile X syndrome. Cell 1991;65:905-914 
3. Oberle I, Rousseau F, Heitz D, et al. Instability of a 550-base pair DNA segment and abnormal methylation in fragile X syndrome. Science 1991;252: $1097-1102$.

4. Snow K, Doud LK, Hagerman R, Pergolizzi RG, Erster SH, Thibodeau SN. Analysis of a CGG sequence at the FMR-1 locus in fragile X families and in the general population. Am J Hum Genet 1993;53:1217-1228.

5. Fu YH, Kuhl DP, Pizzuti A, et al. Variation of the CGG repeat at the fragile $\mathrm{X}$ site results in genetic instability: resolution of the Sherman paradox. Cell 1991;67:1047-1058.

6. Sutcliffe JS, Nelson DL, Zhang F, et al. DNA methylation represses FMR-1 transcription in fragile X syndrome. Hum Mol Genet 1992;1:397-400.

7. McConkie-Rosell A, Lachiewicz AM, Spiridigliozzi GA, et al. Evidence that methylation of the FMR-I locus is responsible for variable phenotypic expression of the fragile X syndrome. Am J Hum Genet 1993;53:800-809.

8. Pieretti M, Zhang FP, Fu YH, et al. Absence of expression of the FMR-1 gene in fragile X syndrome. Cell 1991;66:817-822.

9. Bell MV, Hirst MC, Nakahori Y, et al. Physical mapping across the fragile X: hypermethylation and clinical expression of the fragile $\mathrm{X}$ syndrome. Cell 1991;64:861-866.

10. Ashley CT Jr, Wilkinson KD, Reines D, Warren ST. FMR1 protein: conserved RNP family domains and selective RNA binding. Science 1993;262: 563-566.

11. Loesch DZ, Hay DA, Mulley J. Transmitting males and carrier females in fragile X-revisited. Am J Med Genet 1994;51:392-399.

12. Cornish KM, Munir F, Cross G. Differential impact of the FMR-1 full mutation on memory and attention functioning: a neuropsychological perspective. J Cogn Neurosci 2001;13:144-150.

13. Bennetto L, Pennington BF, Porter D, Taylor AK, Hagerman RJ. Profile of cognitive functioning in women with the fragile X mutation. Neuropsychology 2001;15:290-299.

14. Jakala P, Hanninen T, Ryynanen M, et al. Fragile-X: neuropsychological test performance, CGG triplet repeat lengths, and hippocampal volumes. J Clin Invest 1997;100:331-338.

15. Tassone F, Hagerman RJ, Taylor AK, Gane LW, Godfrey TE, Hagerman PJ. Elevated levels of FMR1 mRNA in carrier males: a new mechanism of involvement in the fragile-X syndrome. Am J Hum Genet 2000;66:6-15.

16. Tassone F, Hagerman RJ, Taylor AK, et al. Clinical involvement and protein expression in individuals with the FMR1 premutation. Am J Med Genet 2000;91:144-152.

17. Kenneson A, Zhang F, Hagedorn CH, Warren ST. Reduced FMRP and increased FMR1 transcription is proportionally associated with CGG repeat number in intermediate-length and premutation carriers. Hum Mol Genet 2001; 10:1449-1454

18. Primerano B, Tassone F, Hagerman RJ, Hagerman P, Amaldi F, Bagni C. Reduced FMR1 mRNA translation efficiency in fragile $\mathrm{X}$ patients with premutations. RNA 2002;8:1482-1488.

19. Hagerman RJ, Leehey M, Heinrichs W, et al. Intention tremor, parkinsonism, and generalized brain atrophy in male carriers of fragile X. Neurology 2001;57:127-130

20. Jacquemont S, Hagerman RJ, Leehey M, et al. Fragile X premutation tremor/ ataxia syndrome: molecular, clinical, and neuroimaging correlates. Am J Hum Genet 2003;72:869-878.

21. Hagerman PJ, Hagerman RJ. The fragile-X premutation: a maturing perspective. Am J Hum Genet 2004;74:805-816.

22. Cohen S, Masyn K, Adams J, et al. Molecular and imaging correlates of the fragile X-associated tremor/ataxia syndrome. Neurology 2006;67:1426-1431.

23. Loesch DZ, Litewka L, Churchyard A, Gould E, Tassone F, Cook M. Tremor/ataxia syndrome and fragile $\mathrm{X}$ premutation: diagnostic caveats. J Clin Neurosci 2007; 14:245-248.

24. Loesch DZ, Cook M, Litewka L, et al. A low symptomatic form of neurodegeneration in younger carriers of the FMR1 premutation, manifesting typical radiological changes. J Med Genet 2008;45:179-181.

25. Grigsby J, Brega AG, Jacquemont $\mathrm{S}$, et al. Impairment in the cognitive functioning of men with fragile $\mathrm{X}$-associated tremor/ataxia syndrome (FXTAS). J Neurol Sci 2006;248:227-233.

26. Hagerman RJ, Leavitt BR, Farzin F, et al. Fragile-X-associated tremor/ataxia syndrome (FXTAS) in females with the FMR1 premutation. Am J Hum Genet 2004; $74: 1051-1056$

27. Cohen J. A power primer. Psychol Bull 1992;112:155-159.

28. Allingham-Hawkins DJ, Brown CA, Babul R, et al. Tissue-specific methylation differences and cognitive function in fragile $\mathrm{X}$ premutation females. Am J Med Genet 1996;64:329-333.

29. Johnston C, Eliez S, Dyer-Friedman J, et al. Neurobehavioral phenotype in carriers of the fragile X premutation. Am J Med Genet 2001;103:314-319.

30. Reiss AL, Freund L, Abrams MT, Boehm C, Kazazian H. Neurobehavioral effects of the fragile $\mathrm{X}$ premutation in adult women: a controlled study. $\mathrm{Am} J$ Hum Genet 1993;52:884-894.

31. Thompson NM, Gulley ML, Rogeness GA, et al. Neurobehavioral characteristics of CGG amplification status in fragile X females. Am J Med Genet 1994;54:378-383.

32. Allen EG, Sherman S, Abramowitz A, et al. Examination of the effect of the polymorphic CGG repeat in the FMR1 gene on cognitive performance. Behav Genet 2005;35:435-445.

33. Franke P, Leboyer M, Hardt J, et al. Neuropsychological profiles of FMR-1 premutation and full-mutation carrier females. Psychiatry Res 1999;87:223-231.

34. Lachiewicz AM, Dawson DV, Spiridigliozzi GA, McConkie-Rosell A. Arithmetic difficulties in females with the fragile X premutation. Am J Med Genet A 2006; 140:665-672.

35. Franke P, Leboyer M, Gansicke M, et al. Genotype-phenotype relationship in female carriers of the premutation and full mutation of FMR-1. Psychiatry Res 1998;80:113-127.

36. Hessl D, Tassone F, Loesch DZ, et al. Abnormal elevation of FMR1 mRNA is associated with psychological symptoms in individuals with the fragile X premutation. Am J Med Genet B Neuropsychiatr Genet 2005; 139:115-121.

37. Sobesky WE, Taylor AK, Pennington BF, et al. Molecular/clinical correlations in females with fragile X. Am J Med Genet 1996;64:340-345.

38. Sobesky WE, Pennington BF, Porter D, Hull CE, Hagerman RJ. Emotional and neurocognitive deficits in fragile X. Am J Med Genet 1994;51:378-385.

39. Lewis P, Abbeduto L, Murphy M, et al. Psychological well-being of mothers of youth with fragile $\mathrm{X}$ syndrome: syndrome specificity and within-syndrome variability. J Intellect Disabil Res 2006;50(Pt 12):894-904.

40. Loesch DZ, Bui QM, Grigsby J, et al. Effect of the fragile X status categories and the fragile $\mathrm{X}$ mental retardation protein levels on executive functioning in males and females with fragile X. Neuropsychology 2003;17:646-657.

41. Loesch DZ, Huggins RM, Bui QM, et al. Effect of fragile X status categories and FMRP deficits on cognitive profiles estimated by robust pedigree analysis. Am J Med Genet A 15 2003;122:13-23.

42. Moore CJ, Daly EM, Schmitz N, et al. A neuropsychological investigation of male premutation carriers of fragile X syndrome. Neuropsychologia 2004;42: 1934-1947.

43. Cornish K, Kogan C, Turk J, et al. The emerging fragile X premutation phenotype: evidence from the domain of social cognition. Brain Cogn 2005; 57:53-60

44. Aziz M, Stathopulu E, Callias M, et al. Clinical features of boys with fragile $\mathrm{X}$ premutations and intermediate alleles. Am J Med Genet B Neuropsychiatr Genet 2003;121:119-127.

45. Farzin F, Perry H, Hessl D, et al. Autism spectrum disorders and attentiondeficit/hyperactivity disorder in boys with the fragile X premutation. $J$ Dev Behav Pediatr 2006;27(suppl 2):S137-S144.

46. Crawford DC, Acuna JM, Sherman SL. FMR1 and the fragile X syndrome: human genome epidemiology review. Genet Med 2001;3:359-371.

47. Sobesky WE, Hull CE, Hagerman RJ. Symptoms of schizotypal personality disorder in fragile X women. J Am Acad Child Adolesc Psychiatry 1994;33: $247-255$.

48. Riddle JE, Cheema A, Sobesky WE, et al. Phenotypic involvement in females with the FMR1 gene mutation. Am J Ment Retard 1998;102:590-601.

49. Simon JA, Keenan JM, Pennington BF, Taylor AK, Hagerman RJ. Discourse processing in women with fragile $\mathrm{X}$ syndrome: evidence for a deficit establishing coherence. Cogn Neuropsychol 2001;18:1-18.

50. Franke P, Maier W, Hautzinger $M$, et al. Fragile-X carrier females: evidence for a distinct psychopathological phenotype? Am J Med Genet 1996;64:334-339. 